\title{
The Influence Of Transformational Leadership, Power Distance, And Followership On The Capability Of Decision Making In Kostrad
}

\author{
Burhanudin Amin \\ Universitas Negeri Jakarta \\ Email: burhanudinamin_im16s3@mahasiswa.unj.ac.id \\ Hamidah \\ Universitas Negeri Jakarta \\ Email: hamidah@unj.ac.id \\ Kazan Gunawan \\ Universitas Negeri Jakarta \\ Email: kazangunawan@yahoo.com
}

\begin{abstract}
The purpose of the study is to analyze the influences of Transformational Leadership, Power Distance and Followership on the Capability of Officers' Decision Making in Kostrad (The Army Strategic Command). The research method used is the survey method which is taken from 293 respondents and associative research explanations using the quantitative research. The writer uses path analysis as the data analysis techniques. The results of the study shows that (1) Transformational Leadership has a direct positive effect on Decision Making Capabilities, (2) Power Distance has a direct positive effect on Decision Making Capabilities, (3) Followership has a direct positive effect on Decision Making Capabilities, (4) Transformational leadership has a direct positive on Followership, (5) Power Distance has a direct positive effect on Followership, (6) Transformational leadership has a direct positive effect on Power Distance, (7) Transformational leadership has an positive indirect effect on Decision Making Capabilitry throuh Power Distance, (8) Transformational leadership has a positive indirect effect on Decision Making Capabilities through Followership. (9) Power Distance has a positive indirect effect on Decision Making Capabilities through Followership. These findings are important because they can be used in the effort for strengthening the capabilities of decision making of the officers in Kostrad.
\end{abstract}

Keywords: Transformational Leadership, Power Distance, Followership, Decision Making Ability of Kostrad Officers.

Received: 5 February 2020 ;

Accepted: 21 February 2020 ;

Publish; June 2020.

How to Cite:

Amin, B., Hamidah., \& Gunawan, K. (2020). The Influence Of Transformational Leadership, Power Distance, And Followership On The Capability Of Decision Making In Kostrad. Journal of Business and Behavioural Entrepreneurship, 4(1), 43-61. https://doi.org/10.21009/JOBBE.004.1.04 


\section{INTRODUCTION}

In accordance to Law No. 34 of 2004 concerning about the Indonesian Armed Forces which explains that the TNI plays an important role and as an instrument of the state in the field of defense by carrying out tasks based on state policy and political decisions. Therefore, the main task of the TNI is to uphold the national sovereignty, maintain the territorial integrity of the Unitary State of the Republic of Indonesia based on Pancasila and the 1945 Constitution, and protect the entire nation to all of Indonesia's blood spills from threats and disturbances to the integrity of the state and nation. Furthermore, the TNI as a national defense functions such as: (1) an antidote to any form of military threat and armed threats from outside and within the country against sovereignty, territorial integrity, and national security, (2) an action against any form of threat and (3) the recovery of state security conditions that are disturbed by turmoil security.

The Army Strategic Command (Kostrad), which is part of the Army, has the main task of organizing the OMP and or OMSP in order to support the basic tasks of the Indonesian Army. Management is the science associated with an organization, especially in achieving organizational goals under the certain conditions. For achieving that goal, the organization must behave as effectively and efficiently as possible by carrying out the functions of planning, organization, implementation and supervision. The implementation of management in the country defense is called the defense management. According to Supriyatno, it is explained that defense management is a process of managing national resources into the potential resources, fostering strength / ability to use them effectively and efficiently to enhance national defense, (Supriyatno, 2014).

A leader in a national defense organization is indeed very necessary. According to Yukl, it is a process to influence followers (Montgomery, 2011). Leaders have various types of leadership based on the type of leader who carries out an organization. One of them is transformational leadership, in which the perspective is continually being expanded. Transformational leadership is a picture of charismatic and inspirational leaders. The leader intellectually stimulates all followers thereby promoting rationality and problem solving skills. The leader also provides individual consideration to followers and expects to attend and provide the growth and development of an organization. There are a number of theoretical statements that show that transformational leadership increases the influence of organizational behavior created by these leaders to followers.

At this time, when the Indonesian Armed Forces (TNI) leaders are in a confronted condition which is not fighting, the current conditions of providing organizational change demands to continue to keep up with the changing times. The organizational change requires a leader to be able to transform, but a leader who has a decision making must have a distance power, it is a Power Distribution meaning according to Kirkman et al. , Chen, Farh, Chen, \& Lowe, 2009). According to Lee, leaders usually understand the right to allocate the resources, rewards and give punishment. With this condition, subordinates must be more sensitive. The mismatches power must be careful when leaders interact with superiors, (Lee Choong Y, 2012). According to Bochner and Hesketh, leaders with high power distance orientation are more task-oriented and less people-oriented than leaders with lower power orientation, (Bochner \& Hesketh, 1994). Thus, according to Madlock, the superior-subordinate relationship is limited to their daily work, which is caused a lack of outside communication. So, leaders with a low power orientation can emphasize shared equality, but ignore the power differences, which is good for active supervisor-subordinate communication and have good relations. As a result, subordinates will not worry about the potential negative effects derived from seeking help from their superiors, (Madlock, 2012). In addition to a leader who has a distance power, the condition of the organization in the TNI that does not have a battle has an impact on leadership style that can affect to Followership.

* The Influence Of Transformational Leadership, Power Distance, And Followership On The Capability Of Decision Making In Kostrad. 
Van Vugt, Hogan, and Kaiser describe leadership and followers develop to facilitate the ability of a leader to influence followers, it continues to develop and to serve at least three adaptive functions that can be known, such as directing group action, mediating conflict within groups, and managing competition between groups. They further suggest that the mechanism of followership leader is evaluated and asked to help individuals detect a leader's trust and to assess the benefits of following the leader or not. Leadership followers have a tendency to distrust the leader, so that every decision making strategic always follows the trust of others. It gives the impact of how the types of followership leader in decision making, (Vugt, Hogan, \& Kaiser., N.d.).

The officers' capabilities to make apt decision is needed during war as well as not war era. Due to the fog of war and battlefield situations, apt decision have to be made as quickly as possible. During the not war era, where the strategic environment is volatile, uncertain, complex and ambiguous, the high ability of the officers to make apt decisions is also imperative. During this era, especially in the field of human resource management, the decision may not affect instanly, but in the long run the effect will be tremendous.

\section{LITERATURE REVIEW}

The meaning of ability according to Robbins and Judge means that the capacity of the individual to perform various tasks in a job, (Robbins \& Judge, 2008a). While the meaning of ability according to Kreitner and Kinicki is the broad characteristics and stable characteristics of responsibility at the maximum level of achievement which is contrary with the ability to physically and mentally work (Kreitner \& Kinicki, 2014).

Decision making is always related to a problem or difficulty. Through a decision and its application, people expect that something will be achieved to resolve the problem or the conflict. Literally, decision making meaning according to Terry is "cutting" (deciding or practically reaching a conclusion). Then, formally the meaning of decision making can be defined as follows: "Decision making is the selection based on criteria from two or more possible alternatives" ("as a choice based on certain criteria regarding to certain behavioral alternatives rather than two or more alternatives") (Terry, 2006a).

Terry explains the basics of decision making that can be applied as follows: (1) Intuition is a decision made based on intuition or feelings that are more subjective, which means it is easily subjected to suggestion, outside influences, and other mental factors. (2) Experience, in this case, experience can be indeed used as a guide in solving problems. (3) Facts, decisions based on a number of facts, data or information that is sufficient and indeed a good and solid decision. (4) Authority, decisions based on more authority which will lead to routine nature. (5) Rational, rational decisions relating to usability, (Terry, 2006a). Thus, the basics needed in decision making are Intuition, Experience, Facts, Authority and Rational.

According to Robbins and Judge transformational leadership is leadership that inspires followers to put aside their personal interests and has an extraordinary ability to influence (Robbins \& Judge, 2008b). Thus, transformational leadership can inspire members or followers. Furthermore, the characteristics of transformational leadership according to Bass in Robbins and Judge are: (1) The ideal influence: giving vision and mission, instilling pride, and gaining respect and trust, (2) Inspirational motivation: high expectations communication, such as using symbols to focus efforts and stating important goals simply. (3) Intellectual stimulation: increasing intelligence, rationality and careful problem solving and (4) Individualized consideration: giving personal attention, such as treating each employee individually, training and giving advice, (Bass, 2008).

Transformational leadership has exceptional and impressive advantages with high productivity and greater employee's satisfaction and service. According to Bass's formula-

* $\quad$ The Influence Of Transformational Leadership, Power Distance, And Followership On The Capability Of Decision Making In Kostrad. 
tion in Yukl, said that the characteristics of transformational leadership are, (1) Ideal Influence (Charisma), such as giving vision and mission, instilling pride, gaining trust, (2) Inspiration, such as communicating high expectations using symbols and focus to efforts, expressing important purposes in simple ways, (3) Intellectual stimulation, such as promoting intelligence, rationality and careful problem solving, (4) Individual considerations, such as giving personal attention, treating each employee individually, training and advising (Bass, 2007). Based on the expert opinion above, it can be concluded that transformational leadership is leadership that can inspire followers in achieving goals. Transformational leader characteristics include that ideal influence, such as inspirational motivation, intellectual stimulation and individualized consideration.

Furthermore, the meaning of power distance according to Hofstede et.al (2010) is the level of acceptance of less powerful institutional members and organizations in a country for expecting and receiving power to be distributed unevenly. One dimension of national culture (from small to large). Thus, power distance can be defined as the level of existence of institutions and organizations members that are less strong in a country by expecting and receiving unevenly power distribution. Institutions are basic elements of society, such as families, schools and communities. Organization is a place where people work. (Hofstede, Hostede., \& Michael Minkov, 2010).

The cultural dimension according to Hofstede which supports the low power distance (Small Power Distance) expects and accepts the consultative or democratic power relations. People relate to each other regardless of their formality position. Subordinates feel more comfortable and demand the right to contribute the decision making. Such as in countries with large power distances, they tend to use power relations that are more autocratic and paternalistic. Subordinates recognize the power of others only based on which they are in a formal structure or a certain hierarchical position. Thus, the power distance index which is defined by Hofstede does not reflect to objective differences in power distribution, but rather to the way people perceive difference power. (Hofstede, 2010)

Based on the description above, it can be concluded that power distance is the level of members who can be able to receive unequal power distribution in an organization with dimensions, which means (1) that support the low power distance (Small Power Distance) for expecting and accepting power relations more consultatively or democratically and (2) by high power distances which tend to use more autocratic power relations.

Although Gardner and others have recognized the importance of leaders and followers who are working together in order to realize the vision, the literature usually pays little attention to the concept of followership, and there is no "theory" of followership. One of the initial discussions of followership was delivered by (Pittman, Rosenbach, Potter), which outlined four types, namely:

a. Subordinates: Similar like "sheep", do what they told, but they are not actively involved.

b. Contributors: "Yes" people, supportive, engaging, doing good work, but they do not have a willing to challenge ideas from leaders.

c. Politicians: Willing to give honest and supportive feedback to leaders, but they may neglect work and have poor performance levels.

d. Partners: High level involved, performed at a high level, promoted positive relationships in groups, seen as 'leaders in waiting,' (Gardner, 2007).

So, the types of followership among them are subordinates, contributors, politicians and partners. Based on the description above, it can be concluded that followership is an act of someone who has a subordinate role and cooperates with the leader in supporting organizational goals which have several types of followers including such as subordinates, contributors, politicians and partners. 
The influence of those independent variables, i.e. Transformational Leadership, Power Distance, and Followership respectively on Decision Making Ability as an independent variable and also the influence of Transformational Leadership and Power Distance respectively on Followership are theorized by some scholars. Such as Decision Making Ability is influenced positively by Transformational Leadership (Yukl, 2007), Power Distance (Hofstede, 2010), and Followership (MacGregor Burn, 2008) respectively. Followership is influenced positively by Transformational Leadership (Terry) and Power Distance (Seng Men Liu and Jian Qiau Liau) respectively.

\section{RESEARCH METHOD}

The applied research method uses is a survey method from 293 respondents combined with the associative research explanations through the quantitative research. The collecting data technique is using the questionnaires the primary data and observational studies and documentation from the Kostrad as the secondary data. First, the writer conducts the direct observations research in the Kostrad environment in Java. Second, the writer interviews the informants who are related to the research variables. Third, the writer spread the research questionnaire to respondents to obtain results. Furthermore, the writer uses the path analysis as the data analysis technique.

The lattice instruments of decision making ability are namely:

Table 1. The lattice instruments of decision making ability

\begin{tabular}{|c|c|c|c|c|c|}
\hline \multirow[t]{2}{*}{ No. } & \multirow[t]{2}{*}{ Dimension } & \multirow[t]{2}{*}{ Indicator } & \multicolumn{3}{|c|}{ Questioner Lists } \\
\hline & & & Before & After & Invalid \\
\hline \multirow[t]{3}{*}{1 . } & \multirow[t]{3}{*}{ Intuition } & Suggestion & 1,2 & 1,2 & \\
\hline & & Outside Influence & 3,4 & 3,4 & \\
\hline & & Spiritual Factors & 5,6 & 5,6 & \\
\hline 2. & \multirow[t]{2}{*}{ Experience } & Background & 7,8 & 7,8 & \\
\hline & & Practical Experience & 9,10 & 9,10 & \\
\hline 3. & \multirow[t]{2}{*}{ Fact } & Data Report & 11,12 & 11,12 & \\
\hline & & Information & 13,14 & 13,14 & \\
\hline 4. & \multirow[t]{2}{*}{ Authority } & Regular Authority & 15,16 & 15,16 & \\
\hline & & Practical Authority & 17,18 & 17,18 & \\
\hline 5. & \multirow[t]{2}{*}{ Rational } & Efficiency & 19,20 & 19,20 & \\
\hline & & Objective & 21,22 & 21 & 22 \\
\hline & & & 22 & 21 & 1 \\
\hline
\end{tabular}

Source: George R. Terry (2006)

The lattice instruments of Transformational Leading Power distance and Followership as follows:

* The Influence Of Transformational Leadership, Power Distance, And Followership On The Capability Of Decision Making In Kostrad.

* $\quad$ https://doi.org/10.21009/JOBBE.004.1.04 
Table 2. The lattice instruments of Transformational Leading Power distance and Followership

\begin{tabular}{|c|c|c|c|c|c|}
\hline No. & \multirow[t]{2}{*}{ Dimension } & \multirow[t]{2}{*}{ Indicator } & \multicolumn{3}{|c|}{ Questioner Lists } \\
\hline & & & Before & After & Invalid \\
\hline \multirow[t]{3}{*}{1.} & \multirow{3}{*}{$\begin{array}{l}\text { Ideal Influence } \\
\text { (Charisma) }\end{array}$} & Vision and Mision & 1,2 & 1,2 & \\
\hline & & Proud & 3,4 & 3,4 & \\
\hline & & Belief & 5,6 & 5,6 & \\
\hline \multirow[t]{3}{*}{2.} & \multirow{3}{*}{ Inspiration } & High Expectation & 7,8 & 7,8 & \\
\hline & & Struggle & 9,10 & 9,10 & \\
\hline & & Simple Intention & 11,12 & 11,12 & \\
\hline \multirow[t]{3}{*}{3.} & & Cleverness & 13,14 & 13,14 & \\
\hline & \multirow{3}{*}{ Stimulation } & Rationality & 15,16 & 15,16 & \\
\hline & & Problem Solving & 17,18 & 17,18 & \\
\hline \multirow{3}{*}{4.} & & Private Attention & 19,20 & 19,20 & \\
\hline & \multirow{2}{*}{$\begin{array}{l}\text { Individual Con- } \\
\text { sideration }\end{array}$} & I rain & 21,22 & 21,22 & \\
\hline & & Advise & 23,24 & 23,24 & 0 \\
\hline
\end{tabular}

Table 3. The lattice instruments of Power Distance Variable

\begin{tabular}{|c|c|c|c|c|c|}
\hline \multirow[t]{2}{*}{ No. } & \multirow[t]{2}{*}{ Dimension } & \multirow[t]{2}{*}{ Indicator } & \multicolumn{3}{|c|}{ Questioner Lists } \\
\hline & & & Before & After & Invalid \\
\hline \multirow[t]{10}{*}{1.} & Small & Use of Power & 1 & 1 & \\
\hline & Power & The Same Treatment & 2 & 2 & \\
\hline & Distance & Disrespect & 3 & 3 & \\
\hline & & Children's Education & 4 & 4 & \\
\hline & & Roles Inequality & 5 & 5 & \\
\hline & & Consultation & 6 & 6 & \\
\hline & & Majority Vote & 7 & 7 & \\
\hline & & Rare Corruption & 8 & 8 & \\
\hline & & Income Distribution & 9 & 9 & \\
\hline & & Religious Emphasis & 10 & 10 & \\
\hline \multirow[t]{10}{*}{2.} & Large & Legitimacy Power & 11 & 11 & \\
\hline & Power & Teaching Obedience & 12 & 12 & \\
\hline & Distance & Respect & 13 & 13 & \\
\hline & & Teacher Education & 14 & 14 & \\
\hline & & Existential Inequality & 15 & 15 & \\
\hline & & Command Notification & 16 & 16 & \\
\hline & & Revolution & 17 & 17 & \\
\hline & & Corruption Frequent & 18 & 18 & \\
\hline & & Inequality & 19 & 19 & \\
\hline & & Leader's Hierarchy & 20 & 20 & \\
\hline \multicolumn{3}{|r|}{ Total } & 20 & 20 & 0 \\
\hline
\end{tabular}

Source : Geert Hofstede (2010)

* The Influence Of Transformational Leadership, Power Distance, And Followership On The Capability Of Decision Making In Kostrad.

* $\quad$ https://doi.org/10.21009/JOBBE.004.1.04 
Table 4. The lattice instruments of Followership Variable

\begin{tabular}{|c|c|c|c|c|c|}
\hline \multirow[t]{2}{*}{ No. } & \multirow[t]{2}{*}{ Dimension } & \multirow[t]{2}{*}{ Indicator } & & \multicolumn{2}{|c|}{ Questioner Lists } \\
\hline & & & Before & After & Invalid \\
\hline \multirow[t]{3}{*}{1.} & \multirow[t]{3}{*}{ Subordinate } & \multirow{3}{*}{$\begin{array}{l}\text { Follow } \\
\text { Know } \\
\text { Inactive }\end{array}$} & 1,2 & \multirow{3}{*}{$\begin{array}{l}1,2 \\
3,4 \\
5,6\end{array}$} & \multirow{3}{*}{ (2) } \\
\hline & & & 3,4 & & \\
\hline & & & 5,6 & & \\
\hline \multirow[t]{2}{*}{2.} & \multirow[t]{2}{*}{ Contributor } & \multirow{2}{*}{$\begin{array}{l}\text { Supportive } \\
\text { Active } \\
\text { Do not Oppose }\end{array}$} & $\begin{array}{c}7,8 \\
9,10\end{array}$ & \multirow{2}{*}{$\begin{array}{c}7,8 \\
9,10 \\
11,12 \\
\end{array}$} & \\
\hline & & & 11,12 & & \\
\hline \multirow[t]{2}{*}{3.} & \multirow[t]{5}{*}{ Politician } & \multirow{5}{*}{$\begin{array}{l}\text { Feedback } \\
\text { Support } \\
\text { Ignore } \\
\text { Involvement } \\
\text { Performance }\end{array}$} & 13,14 & \multirow{4}{*}{$\begin{array}{c}13,14 \\
15,16 \\
18 \\
19,20 \\
21,22\end{array}$} & \multirow{3}{*}{17} \\
\hline & & & 15,16 & & \\
\hline & & & 19,20 & & \\
\hline 4. & & & 21,22 & & 21,22 \\
\hline & & & 22 & 19 & 3 \\
\hline
\end{tabular}

The Validity and Reliability Test Results for the Decision Making Variable Capability explained that to determine the validity of the questionnaire items, a validity test was carried out using the item scores. The total score of items or r-counts tested by comparing r-table at the real level $=0.05$. Based on the calculation result, it can be seen that there is 1 (one) item that is declared invalid. So, it must be dropped out, such as the item number 22. So, it is only 21 statements from the Decision Making Ability variable used are valid to encompass the research data. After making the items in the questionnaire statement, it is declared valid. Based on the calculation results, the reliability of the Decision Making Ability instrument is 0.910. It shows that the Decision Making Capability instrument is reliable and has high reliability.

Validity and Reliability Test Results for Transformational Leadership Variables. To find out the validity of the questionnaire items, the writer use a validity test by using the scores item with the total or r-counts which is tested by comparing r-table at the real level $=0.05$. Based on the calculation results, it appears that 24 items of the Transformational Leadership variable are valid and can be used to capture the data research.

The reliability test calculation of the questionnaire statement items is made after the items of the questionnaire statement are declared valid. Based on the calculation results, the reliability of the Transformational Leadership instrument is 0.955 . This shows that the Transformational Ability instrument is reliable and has high reliability.

Validity and Reliability Test Results for Power Distance Variables. To find out the validity of the questionnaire items, a validity test is done using item scores with the total score of items or $\mathrm{r}$-counts is tested by comparing $\mathrm{r}$-table at the real level $=0.05$. Based on the calculation results, it appears that all items statement of Power Distance as many as 20 items. It turned out into be valid and can be used to capture research data. Based on the calculation results, the reliability of the Transformational Leadership instrument is 0.935 . This shows that the Power Instrument is reliable and has a high reliability.

Validity and Reliability Test Results for Followership Variables. To find out the validity of the questionnaire items, a validity test is done using the item scores with the

* $\quad$ The Influence Of Transformational Leadership, Power Distance, And Followership On The Capability Of Decision Making In Kostrad. 
total score of items or $r$-counts is tested by comparing $r$-table at the real level $=0.05$. Based on the calculation results, it appears that there are 3 (three) items that are declared invalid. So, they must be dropped out, namely for the statement number 17, 20 and 21 . So, that is only 19 statement items from the Followership variable used are valid for capturing the data research. Calculation of the reliability test items questionnaire statement is made after the items statement questionnaire declared valid. Based on the calculation results, the reliability of the Followership instrument is 0.911 . It shows that the Decision Making Capability instrument is reliable and has high reliability.

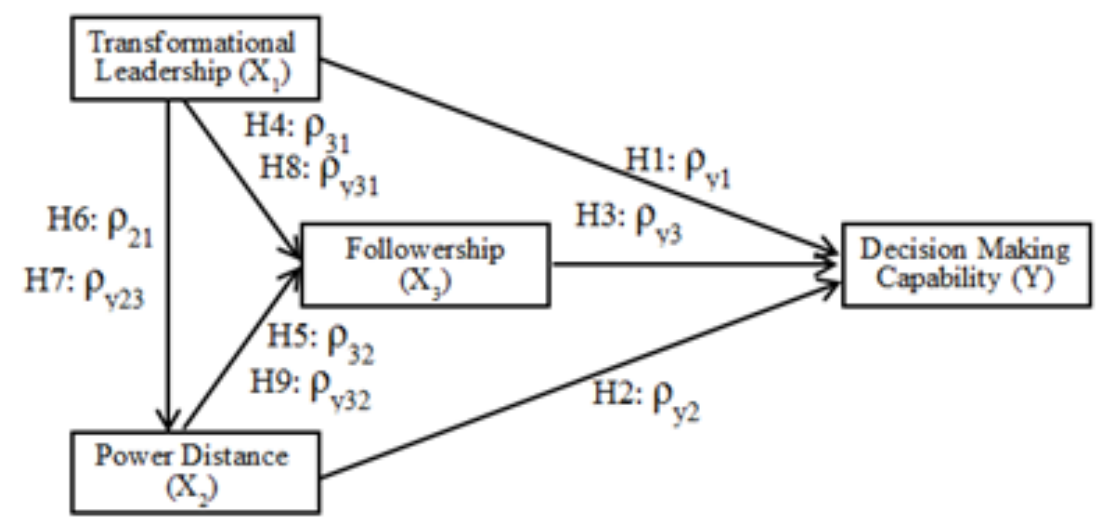

Figure 1. Constellation Research Method Schemes

Based on the description and constellation research scheme model above, the hypotheses research proposed, namely:

H1: Transformational leadership has a direct positive effect on the Kostrad Officers decision making abilities.

H2: Power distance has a direct negative effect on the Kostrad Officers decisionmaking ability.

H3: Followership has a direct positive effect on the Kostrad Officers decision-making ability.

H4: Transformational leadership has a direct positive effect on Kostrad Officers followership.

H5: Power distance has a direct negative effect on Kostrad Officers followership.

H6: Transformational leadership has a direct positive effect on Kostrad Officers Power

Distance.

H7: Transformational leadership has a positive direct effect on the Kostrad Officers Decision Making Ability through Power Distance.

H8: Transformational leadership has a positive indirect effect on the Kostrad Officers Decision Making Ability through Followership.

H9: Power Distance has a positive indirect effect on the Kostrad Officers Decision Making Ability through Followership.

Based on the results of data processing, the results of the data analysis requirements are obtained as follows:

* The Influence Of Transformational Leadership, Power Distance, And Followership On The Capability Of Decision Making In Kostrad.

* $\quad$ https://doi.org/10.21009/JOBBE.004.1.04 
Tabel 5. Data Analysis Requirement Test Result

\begin{tabular}{|l|c|c|c|c|}
\hline Variable & \multicolumn{2}{|c|}{ Normality } & \multicolumn{2}{c|}{ Linearity } \\
\hline Relation & Liliefors.Sig & Conclusion & Anova.Sig & Conclusion \\
\hline $\mathrm{Y}$ atas $\mathrm{X}_{1}$ & $0,0745<0,0760$ & Normal & $0,000<0,05$ & Linear \\
\hline $\mathrm{Y}$ atas $\mathrm{X}_{2}$ & $0,0745<0,0760$ & Normal & $0,000<0,05$ & Linear \\
\hline $\mathrm{Y}$ atas $\mathrm{X}_{3}$ & $0,0745<0,0760$ & Normal & $0,000<0,05$ & Linear \\
\hline $\mathrm{X}_{2}$ atas $\mathrm{X}_{1}$ & $0,0557<0,0760$ & Normal & $0,000<0,05$ & Linear \\
\hline $\mathrm{X}_{2}$ atas $\mathrm{X}_{3}$ & $0,0623<0,0760$ & Normal & $0,000<0,05$ & Linear \\
\hline $\mathrm{X}_{3}$ atas $\mathrm{X}_{1}$ & $0,0557<0,0760$ & Normal & $0,000<0,05$ & Linear \\
\hline
\end{tabular}

Based on the calculation results obtained, the highest L-value or L-hitung $<$ Ltable (0.0760), then the relationship model between variables comes from the normal distribution population. The calculation result, shows that $\mathrm{F}$ is calculated by a significance $<=0.05$. Thus, it can be concluded that the direction coefficient of regression from each model of relationship between variables is linear and very significant, so that the requirements of data analysis can produce validity in the research model.

\section{RESULTS AND DISCUSSIONS}

\section{Descriptive Statistics}

Based on the results of the calculation of validity for the Decision Making Ability variable obtained 21 items that were declared valid. The lowest score is 69 and the highest score is 105 , the range / range of the score is 36 . The average score of decision making ability is 89.8942 , modes is 105 , median is 90.00 , standard deviation or standard deviation is 9,46799 and the variance is 89,643 .

The results of the calculation of validity for the Transformational Leadership variable obtained 24 items that were declared valid. The lowest score is 62 and the highest score is 120 , the range / range of the score is 58. The average value of the Transformational Leadership score is 98.22218 , modes is 120 , the median is 97.00 , the standard deviation is 13.66560 and variance is 186,749 .

The results of the calculation of validity for the Power Distance variable obtained 20 items that were declared valid. The lowest score is 65 and the highest score is 100 , the range / range of the score is 35 . The average score of Power Distance score is 85.9727 , modes is 80 , median is 85.00 , standard deviation or standard deviation is 8,38741 and the variance of 70,349 .

The results of the calculation of validity for the Followership variable found 19 items that were declared valid. The lowest score is 57 and the highest score is 98 , then range of the score is 41 . The average score of Followership score is 80.4232 , modes is 80 , median is 80.00 , standard deviation is 8.90504 and variance is 79,300 .

\section{Path Coefficient Results}

Many previous studies proved empirically the positive effect of Transformational Leadership, Power Distance, and Followership respectively on Decision Making Ability such as the research conducted by Riaz and Haque which stated there is a positive effect of transformational leadership on decision making ability (2016) as well as the result of research conducted by Stump, Troitschanskaia, and Mater (2016). The positive effect of power distance on decision making was stated by Khatri (2009), and also by Khairullah and Khairullah (2013) as the result of their research. Ejimabo (2015) stated that followership has a positive effect on decision making ability Greisser (2007) explained that transformational leadership affect positively on follow-

* $\quad$ The Influence Of Transformational Leadership, Power Distance, And Followership On The Capability Of Decision Making In Kostrad. 
ership, while Cianci et al. (2014) proved empirically this effect on their research. Similar effect of power distance on followership also proved empirically by Elmazi (2012). The positive effect of transformational leadership on power distance was stated by Ismayilov (2011) as a result of their research. In line with those, the author found similar findings as a result of the research conducted in Kostrad as discussed below.

A correlation matrix between research variables is needed in the path analysis structure model.

Table 6. Correlation Matrix of Research Variables

\begin{tabular}{|c|c|c|c|}
\hline No. & Variables Correlation & Result & Conclusion \\
\hline & Substruktural Model 1 & & \\
\hline 1 & $\mathrm{X} 1-\mathrm{Y}$ & 0,504 & Significant \\
\hline 2 & $\mathrm{X} 2-\mathrm{Y}$ & 0,514 & Significant \\
\hline 3 & $\mathrm{X} 3-\mathrm{Y}$ & 0,683 & Significant \\
\hline & Substruktural Model 2 & & Significant \\
\hline 4 & $\mathrm{X} 1-\mathrm{X} 3$ & 0,411 & Significant \\
\hline 5 & $\mathrm{X} 2-\mathrm{X} 3$ & 0,564 & \\
\hline & Substruktural Model 1 & & Positive and Significant \\
\hline 6 & $\mathrm{X} 1-\mathrm{X} 2$ & 0,449 & \\
\hline
\end{tabular}

Based on Table 6 above, it shows that all correlation coefficients between variables are positive. This shows that there is a positive relationship between variables contained in the structural model with significant namely $\alpha=0.01$. In addition, the results of the correlation coefficient can obtain 6 (six) direct effects and 3 (three) indirect effects in the path analysis coefficient. t-test results for the path coefficient of the substructural model 1 is the direct effect of Transformational Leadership, Power Distance and Followership on Decision Making Capabilities which can be presented in Table 7 as follows:

Table 7. t-Test Results and Path Structural Model Substructures 1 Direct Effects of Transformational Leadership, Power Distance and Followership on Decision Making Capabilities

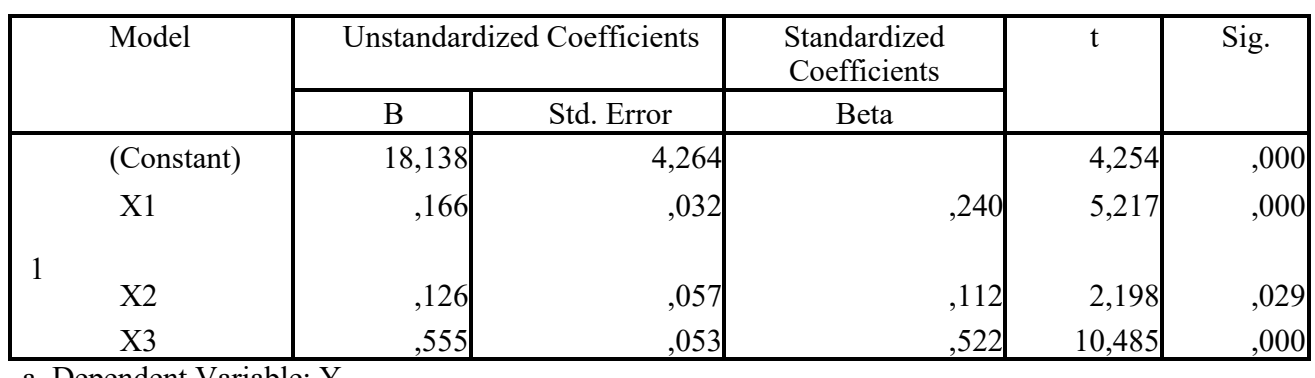

a. Dependent Variable: Y

Based on Table 7, it shows that the results of the Transformational Leadership path coefficient on the Decision Making Capability are obtained py $1=0.240$, then the coefficient of path Power Distance to the Decision Making ability is obtained py $2=0.112$, then the results of the calculation of the Followership path coefficient on the Decision Making Capability obtained py $3=0.522$. Thus, the path diagram for the direct influence of Transformational Leadership, Power Distance and Followership on Decision Making Capabilities is as follows:

* The Influence Of Transformational Leadership, Power Distance, And Followership On The Capability Of Decision Making In Kostrad.

* https://doi.org/10.21009/JOBBE.004.1.04 


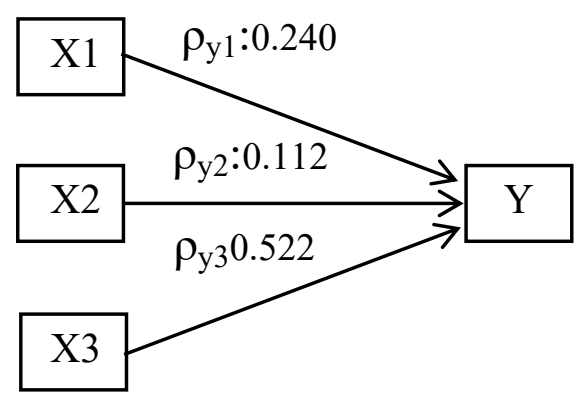

Figure 2. Path coefficient Direct Effect of Transformational Leadership, Power Distance and Followership on Decision Making Capabilities

T-test results for the path coefficient of the substructural model 2 is the direct influence of Transformational Leadership and Power Distance on Followership that can be presented in Table 8 as follows:

Table 8. t-Test Results for Substructural Model Coefficients 2 Direct Effects of Transformational Leadership and Power Distance towards Followership

\begin{tabular}{|l|r|r|r|r|r|}
\hline \multirow{2}{*}{ Model } & \multicolumn{2}{|c|}{ Unstandardized Coefficients } & \multicolumn{1}{c|}{$\begin{array}{c}\text { Standardized } \\
\text { Coefficients }\end{array}$} & \multicolumn{1}{c|}{ Sig. } \\
\cline { 2 - 4 } & \multicolumn{1}{|c|}{ B } & Std. Error & \multicolumn{1}{c|}{ Beta } & \\
\hline \multirow{2}{*}{ (Constant) } & 24,341 & 4,511 & & 5,396 &, 000 \\
1 &, 129 &, 035 &, 198 & 3,732 &, 000 \\
X1 &, 505 &, 056 &, 476 & 8,981 &, 000 \\
\hline
\end{tabular}

Based on Table 8 above, it shows that the results of the path coefficient of Transformational Leadership to Followership is $\mathrm{p} 31=0.198$ and the Power Distance path coefficient to Followership is $\mathrm{p} 32=0.476$. Thus, the path diagram for the direct influence of Transformational Leadership and Power Distance on Followership is as follows:

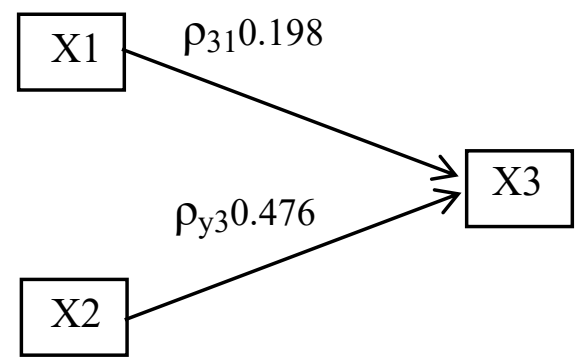

Figure 3. Path coefficient Direct Effect of Transformational Leadership and Power Distance on Followership

t-test results for the path coefficient for substructural model 3, namely the direct influence of Transformational Leadership on Power Improvement can be presented in Table 9 as follows:

* The Influence Of Transformational Leadership, Power Distance, And Followership On The Capability Of Decision Making In Kostrad.

* $\quad$ https://doi.org/10.21009/JOBBE.004.1.04 
Table 9. t-Test Results for Substructural Model Coefficients 3 Direct Effects of Transformational Leadership and Power Distance towards Followership

\begin{tabular}{|c|c|c|c|c|c|}
\hline \multirow[t]{2}{*}{ Model } & \multicolumn{2}{|c|}{ Unstandardized Coefficients } & Standardized & \multirow[t]{2}{*}{$\mathrm{t}$} & \multirow[t]{2}{*}{ Sig. } \\
\hline & B & Std. Error & Beta & & \\
\hline (Constant) & 58,935 & 3,189 & & 18,481 &, 000 \\
\hline $\mathrm{X} 1$ & 275 & 032 & ,449 & 8,560 & ,000 \\
\hline
\end{tabular}

Based on Table 9 above, it shows that the results of the calculation of the path coefficient of Transformational Leadership to Power Distribution obtained p21 $=0.449$. Thus, the path diagram of the direct influence of Transformational Leadership on Power Distance is as follows:

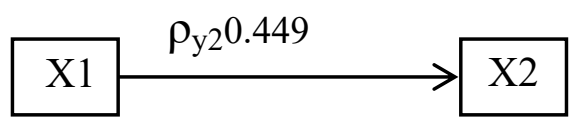

Figure 4. Path coefficient Direct Effect Direct Effect Transformational Leadership towards Power Distance

Based on Table 9 above, the direct or indirect effects can be seen in the table as follows:

Table 10. Direct Influence, Indirect Influence and Total Influence Against the Decision Making Capability

\begin{tabular}{|c|c|c|c|c|c|c|}
\hline Variable & Path & Direct & \multicolumn{3}{|c|}{ Indirect Influence } & \multirow{2}{*}{$\begin{array}{c}\text { Total } \\
\text { Influence }\end{array}$} \\
\hline Correlation & Coefficient & Influence & $\begin{array}{c}\text { Transformational } \\
\text { Leadership }\end{array}$ & $\begin{array}{c}\text { Power } \\
\text { Distance }\end{array}$ & Followership & \\
\hline $\begin{array}{l}\text { Transformational } \\
\text { Leadership } \\
\end{array}$ & 0,240 & 0,0576 & & 0,0121 & 0,0515 & 0,1212 \\
\hline Power Distance & 0,112 & 0,0125 & 0,0121 & & 0,0330 & 0,0576 \\
\hline Followership & 0,522 & 0,2725 & 0,0515 & 0,0330 & & 0,3569 \\
\hline Total Inf & uence & & & & & $\mathbf{0 , 5 3 5 7}$ \\
\hline
\end{tabular}

Based on Table 10 above, it shows that the path coefficient of the indirect influence of Transformational Leadership on Decision Making Capability through Power Distance variable mediation is y21 $=(0.449)(0.112)=0.050$, then the path coefficient of indirect influence on Transformational Leadership on Decision Capability through mediation of Followership variables is y31 $=(0.198)(0.522)=0.103$. Furthermore, the path coefficient of the indirect influence of Power Distance on Decision Making Capability through mediation of the Followership variable is $\mathrm{y} 32=(0.476)(0.522)=0,248$. Thus, each path diagram can be described as follows: 


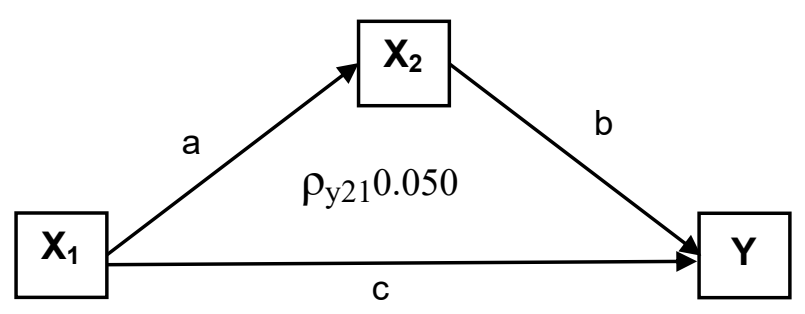

Figure 5. The path coefficient of the indirect effect of transformational leadership on decision making abilities Through Power Distance Variable Mediation

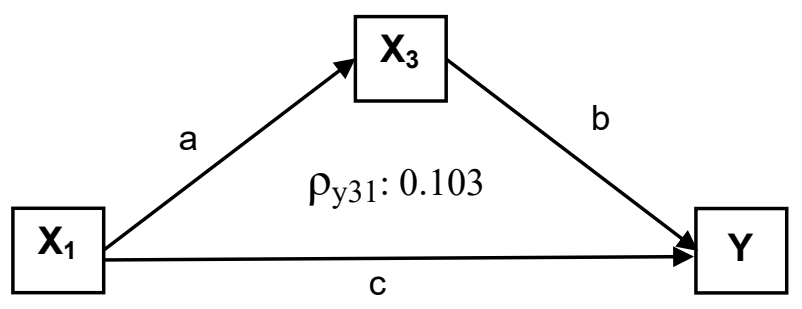

Figure 6. The path coefficient of the indirect effect of transformational leadership on decision making abilities Through Mediation Followership Variables

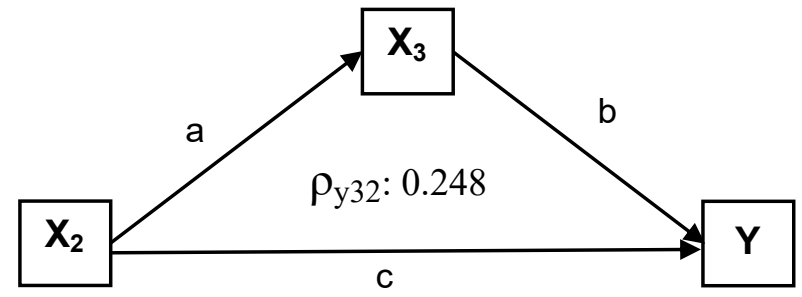

Figure 7. Path coefficient Indirect Effect of Power Distance Against the Capability of Decision Making Through Mediation Followership Variables

The complete model of the research can be seen in Picture- 8 .

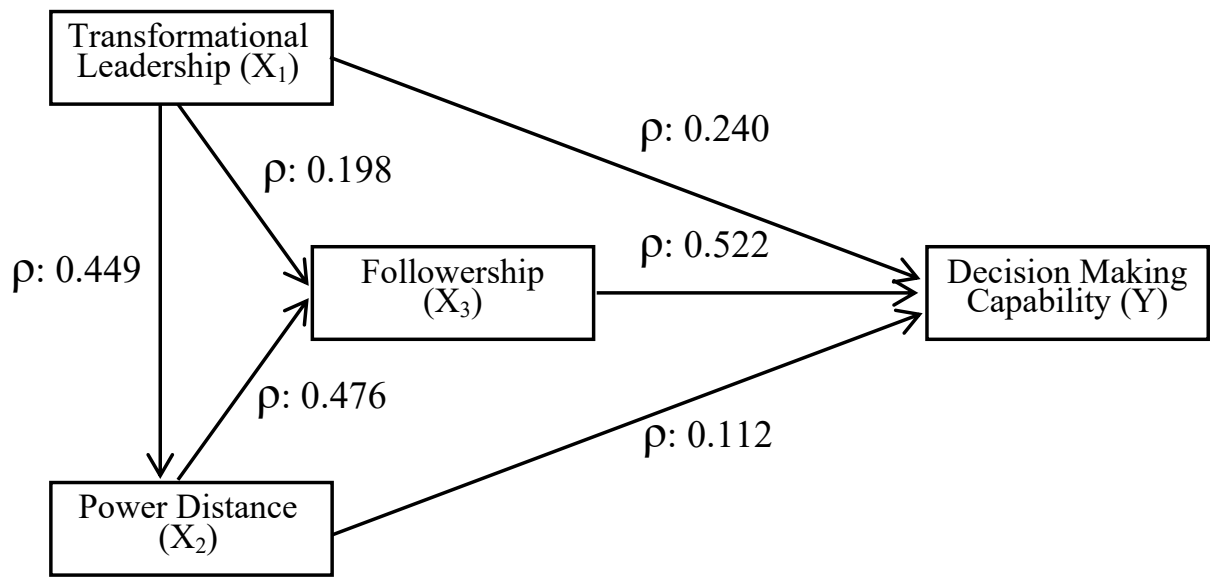

Figure 8. The Complete Model of the Research

* The Influence Of Transformational Leadership, Power Distance, And Followership On The Capability Of Decision Making In Kostrad.

* $\quad$ https://doi.org/10.21009/JOBBE.004.1.04 


\section{Hypothesis Testing}

a. Hypothesis-1 (H1)

Based on Table 7 shows the results of t-hitung $=5.217$ while the value $=1.960$ $(\alpha=0.05)$, because t-hitung $>$ t-table $(\alpha=0.05)$, and py1 $=0.240>0$ so H1 is not rejected, which means that Transformational Leadership has a positive and significant direct effect on Decision Making Capabilities.

b. Hypothesis-2 (H2)

Based on Table 7 shows the results of t-hitung $=2.198$ while the value $=1.960$ $(\alpha=0.05)$, because t-hitung $>$ t-table $(\alpha=0.05)$, and py $2=0.112>0$ so H2is not rejected, which means that Power Distance has a positive and significant direct effect on Decision Making Capabilities.

c. Hypothesis-3 (H3)

Based on Table 7 shows the results of thitung $=10.485$ while the value $=1.960$ $(\alpha=0.05)$, because t-hitung $>$ t-table $(\alpha=0.05)$, and py3 $=0.522>0$ so H3 is not rejected, which means that Followership has a positive and significant direct effect on Decision Making Capability.

d. Hypothesis-4 (H4)

Based on Table 8 shows that t-hitung $=3,732$ while value $=1,960(\alpha=0.05)$, because t-hitung $>$ t-table $(\alpha=0.05)$, and p13 $=0.198>0$ so H4 is not rejected, which means that Transformational Leadership has a positive and significant direct effect on Followership .

e. Hypothesis-5 (H5)

Based on Table 8 shows that $\mathrm{t}$-hitung $=8.981$ while value $=1.960(\alpha=0.05)$, because $\mathrm{t}$ -hitung $>$ t-table $(\alpha=0.05)$, and p23 $=0.476>0$ so H5 is not rejected, which means that Power Distance has a positive and significant direct effect towards Followership.

\section{f. Hypothesis-6 (H6)}

Based on Table 9 shows that $\mathrm{t}$-hitung $=8.560$ while value $=1.960(\alpha=0.05)$, because $\mathrm{t}$ -hitung $>$ t-table $(\alpha=0.05)$, and p21 $=0.321>0$ so H6 is not rejected, which means that Transformational Leadership has a positive and significant direct effect against Power Distance.

g. Hypothesis-7 (H7)

Based on Table 7 and Table 9 which is used the Sobel Test for the hypothesis of indirect effect using the value of $z$, it can be seen as follows:

$\mathrm{Z}=\frac{\mathrm{ab}}{\sqrt{\left(\mathrm{b}^{2} S E \mathrm{a}^{2}\right)+\left(\mathrm{a}^{2} \mathrm{SEb}^{2}\right)}}$

where:

a: Unstandardized regression coefficient of X2 to X1.

b: Unstandardized regression coefficient of $Y$ to $X 2$.

SEa: Standard Error of Estimation of the regression of X2 to X1.

$\mathrm{SEb}$ : Standard Error of Estimation of the regression of $\mathrm{Y}$ to $\mathrm{X} 2$.

* The Influence Of Transformational Leadership, Power Distance, And Followership On The Capability Of Decision Making In Kostrad.

* $\quad$ https://doi.org/10.21009/JOBBE.004.1.04 
$\mathrm{z}==2,140$

The value of $\mathrm{z}>1,96$ so $\mathrm{H} 7$ is not rejected, which means that Transformational Leadership has a positive indirect effect on Decision Making Ability through Power Distance.

h. Hipotesis-8 (H8)

Based on Table 7 and Table 9 which is used the Sobel Test for the hypothesis of indirect effect using the value of $z$, it can be seen as follows:

$\mathrm{Z}=\frac{\mathrm{ab}}{\sqrt{\left(\mathrm{b}^{2} S \mathrm{Ea}^{2}\right)+\left(\mathrm{a}^{2} \mathrm{SEb}^{2}\right)}}$

where:

a: Unstandardized regression coefficient of X2 to X1.

$\mathrm{b}$ : Unstandardized regression coefficient of $\mathrm{Y}$ to $\mathrm{X} 2$.

SEa: Standard Error of Estimation of the regression of X2 to X1.

$\mathrm{SEb}$ : Standard Error of Estimation of the regression of Y to X2.

$\mathrm{z}=3,476$

The value of $\mathrm{z}>1,96$ so $\mathrm{H} 8$ is not rejected, which means that Transformational Leadership has a positive indirect effect on Decision Making Ability through Followership.

\section{i. Hipotesis-9 (H9)}

Based on Table 7 and Table 9 which is used the Sobel Test for the hypothesis of indirect effect using the value of $\mathrm{z}$, it can be seen as follows:

$$
\mathrm{z}=\frac{\mathrm{ab}}{\sqrt{\left(\mathrm{b}^{2} S \mathrm{Ea}^{2}\right)+\left(\mathrm{a}^{2} \mathrm{SEb} \mathrm{b}^{2}\right)}}
$$

where:

a: Unstandardized regression coefficient of X3 to X2.

b: Unstandardized regression coefficient of Y to X3.

SEa: Standard Error of Estimation of the regression of X3 to X2.

$\mathrm{SEb}$ : Standard Error of Estimation of the regression of Y to X3.

$\mathrm{z}=6,833$

The value of $\mathrm{z}>1,96$ so $\mathrm{H} 9$ is not rejected, which means that Power Distance has a positive indirect effect on Decision Making Ability through Followership.

\section{CONCLUSION}

Based on the results of the research and discussion above, we can conclude that (1) Transformational Leadership has a direct positive effect on Decision Making Capability. It means that effective transformational leadership will lead to an increase in Kostrad Officer decision-making abilities. (2) Power Distance has a direct positive effect on Decision Making Capability. This means that high Power Distance will lead to an increase of Kostrad Officers decision-making ability. (3) Followership has a direct positive effect on Decision Making Capability. It means that high Followership will lead to an increase of the Kostrad Officers decision-making ability. (4) Transformational leadership has a direct positive effect on Followership. It means that effective transformational leadership will lead to an increase of Kostrad Officer Followership. (5) Power Distance has a direct positive effect on Followership. It means that high Power Distance will cause an increase of Kostrad Officer Followership. (6) Transformational leadership has a direct positive effect on Power Distance. It means that effec-

* $\quad$ The Influence Of Transformational Leadership, Power Distance, And Followership On The Capability Of Decision Making In Kostrad.

* $\quad$ https://doi.org/10.21009/JOBBE.004.1.04 
tive transformational leadership will lead to an increase of Power Distance. (7) Transformational leadership has a positive indirect effect on Decision Making Capability through the mediation of Power Distance variables. It means that effective Transformational Leadership will lead to an increase on Decision Making Capability through the mediation of Kostrad Officers Power Distance. (8) Transformational leadership has a positive indirect effect on Decision Making Capability through mediation of Followership variables. It means that effective Transformational Leadership will lead to an increase in Decision Making Capability through mediation of the Kostrad Officer Followership and (9) Power Distance has a positive indirect effect on Decision Making Capability through mediation of Followership variables. It means that high Power Distance will lead to an increase in Decision Making Capability through mediation by the Kostrad Officer Followership.

\section{RECOMMENDATION}

Referring to the conclusions, the following suggestions are given as follows (1) To improve decision making ability through transformational leadership. The Kostrad Officers should be able to apply the characteristics of transformational leadership in solving a problem by quickly seeking information that can support the resolution of the problem. (2) To increase the ability and make decisions through power distance. Kostrad officers are able to use their legitimacy power well. So that, there is a balance of power distance between leaders and members and (3) To increase the ability to make decisions through followership. Pay attention and motivate members who have an attitude of neglect towards the given task.

\section{REFERENCES}

Al Azzam, Z. F. (2015). The Effects of Perceived Transformational Leadership Style and Emotional Intelligence on Enhancing the Effectiveness of Decision Making in Public Health Sector. International Journal of Advanced Research, 3(12), 1666-1682.

Alkharabsheh, Z. A. A., \& Abdulrahman, K. (2014). No Title. Procedia - Social and Behavioral Sciences, 129, 282-288.

Arikunto, S. (2011). Prosedur Penelitian :Suatu Pendekatan Praktek. Jakarta: Penerbit Rineka Cipta.

Bass, B. M. (2007). Kepemimpinan. In G. Yukl (Ed.), Kepemimpinan dalam Organisasi (hal. 305). Jakarta: PT Indeks.

Bass, B. M. (2008). From Transactional to Transformasional Leadership: Learning to Share The Vision", Organizational Dynamics. In S. P. Robbins \& T. Judge (Ed.), Perilaku Organisasi (hal. 91). Jakarta: Penerbit Salemba Empat.

Bass, B. M. (2017). Transformational Leadership: Industrial, Military and Educational Impact. In R. L. Taylor., W. E. Rosenbach., \& E. B. Rosenbach (Ed.), Military Leadership : In Pursuit of Excellence. Lieutenant General Gregory S. Newbold (USMC Ret). Bimo, S. (2017). Uji Mediasi Dengan Sobel Test.

Bochner, S., \& Hesketh, B. (1994). Power Distance, Individualism/Collectivism, and JobRelated Attitudes in a Culturally Diverse Work. Journal of Cross Cultural Pyschology, 1(1).

Boerner, Sabine, S. A. E. dan D. G. (2007). Follower Behavior and Organizational Performance: The Impact of Transformational Leaders. Journal of Leadership and Organizational Studies, 13(3), 15.

* The Influence Of Transformational Leadership, Power Distance, And Followership On The Capability Of Decision Making In Kostrad.

* $\quad$ https://doi.org/10.21009/JOBBE.004.1.04 
Bungin, B. (2011). Metodologi Penelitian Kuantitatif, (Komunikasi, Ekonomi dan Kebijakan Publik Serta Ilmu-Ilmu Sosial Lainnya. Jakarta: Penerbit Kencana Prenada Media Group.

Chevalier, R. (2017). A manager's guide to improving workplace performance. United States of America: American Management Association.

Cianci, A. M., Hannah, S. T., Roberts, R. P., \& Tsakumis, G. T. (2014). The effects of authentic leadership on followers' ethical decision-making in the face of temptation: An experimental study. The Leadership Quarterly 25, 581-594.

Coscarelli, W. C., Burk, J., \& CotterA. (2000). HRD and Decision- making styles. In A. T. and V. R. Krishnan (Ed.), Leadership in Decision Making (hal. 69-79). India: Indian Management.

Dumitriu, C., Iulia Cristina Timofti, E. N., \& Dumitriu, G. (2014). The Influence of the Locus of Control and Decision-making Capacity upon the Leadership Style. Procedia -Social and Behavioral Sciences, 141, 494-499.

Ejimabo, N. O. (2015). An Approach to Understanding Leadership Decision Making In Organization. European Scientific Journal, 11(11).

Gardner, J. (2007). On leadership. In R. P. Pittman, D. W. S. Whitebead, \& T. R (Ed.), Essentials of Nursing Leadership and Management (5 ed.). F.A. Davis Company. Gibson, J. L., Donnely., J. H., Konopaske., R., \& Ivancevich, J. M. (2008). Organization: Behavior, Structure, Procesess (11 ed.).

Goolaup, S., \& Ismayilov, T. (2011). The Influence of Power Distance on Leadership Behaviour and Styles. Umea School of Business.

Grossman, S. (2005). Developing Leadership through Shadowing a Leader in Health Care. In H. Greenburg \& F. \& M. (Ed.), Educating for leadership (hal. 266-278). New York: Springer Publishing.

Hariri, H., Monypenny., R., \& Prideaux, M. (2014). Leadership styles and decisionmaking styles in an Indonesian. Article in School Leadership and Management. 2014. School of Business, James Cook University, Australia, 13.

Hofstede, G. (2010). Attitudes, Values and Organizational Culture: Disentangling the Concepts Organization Studies.

Hofstede, G., Hostede., G. J., \& Michael Minkov. (2010). Cultural and Organization. USA.

Howell, J. P., \& Mendez, M. J. (2008). Three perspecties on followership. In R. E. Riggio, I. Chaleff, \& J. Lipman-Blumen (Ed.), The art of followership (hal. 25-39). San Fransisco: CA : Jossey-Bass.

Ji, Y., Zhou., E., Li., C., \& Yan, Y. (2015). Power Distance Orientation and Employee Help Seeking:Trust In Supervisor as a Mediator. Social Behavior and Personality, 43 (6), 1043-1054.

Kadir. (2010). StatistikaUntuk Penelitian Ilmu-Ilmu Sosial. Jakarta: Rosemata Sempurna.

Kelley, R. E. (2015). In Praise of Followers. Harvard Business Review, Reprint 88606.

Khairullah, D. H. Z., \& Khairullah, Z. Y. (2013). Cultural Values and Decisions Making in China. Journal of Business, Humanities and Technology, 3(2), 1.

Khatri, N. (2009). Consequences of Power Distance Orientation Organization. Article in Vision The Journal of Business Perspective.

Kirkman, B. L., Chen, G., Farh, J. L., Chen, Z. X., \& Lowe, K. B. (2009). Individual power distance orientation and follower reactions to transformational leaders: A crosslevel, cross-cultural examination. Academy of Management Journal, 52, 744-764. Kostrad. (2016). Profil Kostrad. Jakarta: Kostrad.

Kreitner, R., \& Kinicki, A. (2014). Perilaku Organisasi (E. Suandy, Ed.). Jakarta: Penerbit Salemba Empat.

Kuncoro, R., \& Achmad, E. (2012). Cara Menggunakan Path Analysis. Bandung: Penerbit Alfabeta.

* The Influence Of Transformational Leadership, Power Distance, And Followership On The Capability Of Decision Making In Kostrad.

* $\quad$ https://doi.org/10.21009/JOBBE.004.1.04 
Lee Choong Y. (2012). Korean Culture And Its Influence on Business Practice in South Korea. Journal of International Management Studies, 7(2), 184.

Liliweri, A. (2007). Makna Budaya dalam Komunikasi Antar Budaya. Bantul: Penerbit LKIS.

Liu, S. M., \& Liau, J. Q. (2013). Transformational Leadership and Speaking Up: Power Distance and Structural Distanceas Moderators. Social Behavior And Personality, 41 (10), 1747-1756.

Liu, W. K., \& Lee, Y. (2012). Evaluation of Relationship between Power Distance and Transformational Leadership: Examination of Multinational Corporations in Taiwan. Journal ICFME, 21.

MacGreggor Burn, J. (2008). Followership. In Ronald E. Riggio, I. Chaleff, \& J. LipmanBlumen (Ed.), The Art of Followership : How Great Followers, Creategreat Leaders and Organization.

MacMillan, K. T. (2013). Leaders, Followers, and the Space Between: A Three Dimensional View of Leader Attention and Decision making. Electronic Thesis and Dissertation Repository, 1778.

Madlock, P. E. (2012). The Link Between Leadership Style, Communicator Competence, and Employee Satisfaction. Journal Business Communication, 45(1), 61-78.

Mathis, R. L., \& Jackson, J. H. (2008). Human Resource Management (D. Angelica, Ed.).Jakarta: Penerbit Salemba Empat.

McShane, \& Glinow, V. (2010). Organizational Behavior. USA: McGraw-Hill. Mohammad, R., \& Saad, N. M. (2016). Power Distance Culture And The Construction Of The Followership Identity. Asia Pacific Institute Of Advanced Research (APIAR), 2 (1), 152.

Montgomery, V. W. (2011). Dyamics of Leadership in Public Service (Second Edi; ME Sharpa Armonh, Ed.). New York.

Nichodemus Obioma, E. (2015). The of Decision Making in Organizational Leadership and Management Activities. Ejimabo : J Entrepren Organization Management, 4(2).

Rehman, R. R. (2012). Transformational Leadership Style as Predictor of Decision Making Styles: Moderating Role of Emotional Intelligence. School of Management Sciences, Quaid-i-Azam University, Islamabad, Pakistan, 6(2), 257-268.

Riaz, M. N., \& Anis-ul-Haque, M. (2016). Leadership Styles As Predictors of Decision Making Styles Among Top, Middle And Lower Managers. Pakistan Business Review, 891.

Rivai, V. (2008). Manajemen Sumber Daya Manusia. Jakarta: PT. RajaGrafindo Persada.

Rivai, V. (2014). Kepemimpinan dan Perilaku Organisasi. Jakarta: PT. RajaGrafindo Persada.

Robbins, S. P., \& Judge, T. (2008a). Perilaku Organisasi. Organizational Behavior (12 ed.; D. Angelica, Ed.). Jakarta: Penerbit Salemba Empat.

Robbins, S. P., \& Judge, T. (2008b). Perilaku Organisasi (2 ed.; A. Diana, Ed.). Jakarta:

Penerbit Salemba Empat.

Schindler, J. H. (2015). Followership : What it Takes it Lead (J. Philips \& S. Gully, Ed.).

Business Expert Press.

Schuster, J. P. (2015). Transforming Your Leadership Style. In L. Wagner (Ed.), Leading Up Transformational Leadership for Fundraisers. New York: John and Willey Sons Corp. Silalahi, U. (2012). Metode Penelitian Sosial (Ketiga). Bandung: Penerbit Refika Aditama. Siswanto, H. (2008). Pengantar Manajemen. Jakarta: Penerbit PT Bumi Aksara.

Soekarso, \& Dkk. (2010). Teori Kepemimpinan. Jakarta: Penerbit PT Mitra Wacana Media. Stump., M., Troitschanskaia., O. Z., \& Mater, O. (2016). The effects of transformational leadership on teachers' data use. Journal for educational research online, 8 (3), 80-99.

* The Influence Of Transformational Leadership, Power Distance, And Followership On The Capability Of Decision Making In Kostrad.

* $\quad$ https://doi.org/10.21009/JOBBE.004.1.04 
Supriyatno, M. (2014). Tentang Ilmu Pertahanan. Jakarta: Yayasan Pustaka Obor Indonesia.

Terry, G. R. (2006a). Asas-Asas Manajemen (Winardi, Ed.). Bandung: Penerbit PT. Alumni.

Terry, G. R. (2006b). Prinsip-Prinsip Manajemen (S. D. J, Ed.). Jakarta: Penerbit PT Bumi Aksara.

Umar, H. (2013). Desain Penelitian MSDM dan Perilaku Karyawan. Jakarta: Penerbit PT Rajawali Pers.

Vugt, V., Hogan, \& Kaiser. (n.d.). Dyamics of Leadership in Public Service (V. W. Montgomery, Ed.). New York: M.E. Sharpa. Armonh.

Walia, A., Mittal, R. B., \& Sanjiv. (2015). Relationship Between Leadership Style And Followership Style. International Journal of Advanced Research in Management and Social Sciences, 4(4), 174-175.

Wirawan. (2007). Budaya dan Iklim Organisasi (Teori Aplikasi dan Penelitian). Jakarta:

Penerbit Salemba Empat.

Yukl, G. (2007). Kepemimpinan dalam Organisasi. Jakarta: PT Indeks.

Zogjani, A., Llaci, S., \& Elmazi, E. (2012). The Role Of Power In Effective Leadership And Followership: The Albanian Case. Romanian Economic and Business Review, 9 (1), 89 .

* The Influence Of Transformational Leadership, Power Distance, And Followership On The Capability Of Decision Making In Kostrad.

* $\quad$ https://doi.org/10.21009/JOBBE.004.1.04 